\section{ZÁKLADNÍ INFRASTRUKTURA ELEKTRONICKÉHO ZDRAVOTNICTVÍ ČR}

\section{Jiří Borej}

\section{Anotace}

Základní infrastrukturou elektronizace zdravotnictví je myšlen soubor informačních systémů a datových zdrojů, které poskytují centrálně sdílené služby garantované státem. Článek se odkazuje na klíčové procesy ve zdravotnictví, jejichž elektronizace tyto služby vyžaduje a uvádí sadu pravidel, kterými se bude rozvoj centrálně budované infastruktury rí́dit. Cílem článku je znázornit vzájemnou provázanost infrastrukturních služeb a poukázat na potřebu koordinace při prípravě a tvorbě nových elektronizovaných agend a tomu odpovídajících informačních systémů. Důraz je kladen na využívání informačních zdrojů resortu zdravotnictví a datové základny České republiky.

Infrastruktura elektronického zdravotnictví je sada komponent, které slouží pacientům a účastníkům v systému zdravotnictví, aby mohli v elektronickém světě využívat elektronické služby a usnadnili si tak komunikaci při zajišťování jejich běžných agend, styku s poskytovateli zdravotních služeb a organizacemi spravující jejich zdravotní data.

Článek uvádí a akcentuje klíčové komponenty architektury, které jsou základem pro rozvoj elektronizace a vztahuje je prioritám stanovených akčním plánem elektronizace.

\section{1 Úvod}

Základní infrastruktura centrálně poskytovaných služeb pro resort zdravotnictví je tvořena několika klíčovými komponenty a datovými zdroji, které jsou provázány na Základní registry eGovernmentu. Tato infrastruktura je tvořena pro potřeby naplnění potřeb a cílů daných Národní strategií elektronického zdravotnictví (dále NSeZ) a priorit rozvoje elektronizace stanovené Akčním plánem k NSeZ 2016 - 2020, který je průběžně aktualizován dle potřeb jednotlivých zadavatelů. Za jejich koordinaci odpovídá Ministerstvo zdravotnictví.

Tyto priority jsou Akčním plánem za rok 2017 stanoveny takto:

1. Zajištění strategického řízení rozvoje elektronického zdravotnictví v resortu $\mathrm{MZ}$

2. ePreskripce

3. Vybudování základní informační infrastruktury eHealth - Integrovaného Datového Rozhraní Rezortu pro komunikaci informačních systémů a sdílení dat (IDRR)

\section{Kybernetická bezpečnost}

Dalšími prioritami jsou aktivity, které jsou řešeny ad hoc bez pevně stanoveného plánu.

5. Sdílení zdravotnické dokumentace, implementační podpora u poskytovatelů zdravotních služeb

6. Telemedicína

7. Budování a rozvoj IS veřejného zdraví a elektronického zdravotnictví ("Portál")

Pro účely tohoto článku budeme rozebírat aspekty realizace základní infrastruktury a identifikujeme potřebné elektronické služby ve vztahu ke stanoveným prioritám.

Klíčovou prioritou je priorita číslo 3 - vytvoření Integrovaného Datového Rozhraní Rezortu (IDRR). Tento nově tvořený centrálně zřizovaný informační systém zabezpečuje propojení na datový fond ČR, zprostředkovává informace, data a referenční údaje účastníkům zdravotnického systému, tak aby mohli v elektronickém světě resortu zdravotnictví využívat elektronické služby a usnadnili si tak komunikaci při zajištování jejich běžných agend, styku s poskytovateli zdravotních služeb a organizacemi spravujícími jejich zdravotní data. Zároveň systém IDRR zajištuje propojení s agendami eGovernmentu, které se bezprostředně týkají každého občana, nebo jeho podnikatelských aktivit. Např́klad vyřizovaní agend sociálního zabezpečení, změn identifikačních a geografických údajů občana.

Následující kapitoly popisují jednotlivé klíčové priority a informační služby, které jsou potřeba pro systémové řešení jednotlivých priorit a mohla se odvodit architektura jednotlivých komponentů a jejich vzájemná provázanost.

\section{Výchozí situace}

Základním východiskem pro návrh centrálně poskytovaných informatických služeb jsou zpracované architektonické vize a plány rozvoje založené na analýze potřeb jednotlivých aktérů $v$ rezortu zdravotnictví. Tyto práce byly provedeny v roce 2016 a dokumenty k jednotlivým zpracovávaným tématům jsou uverejněny na portále Národní strategie elektronického zdravotnictví spravovaným Národním centrem elektronizace zdravotnictví při MZ ČR.

\section{Klíčová řešená architektonická témata.}

- T01 Národní registr poskytovatelů zdravotních služeb, Národní registr zdravotních profesionálů

- T02 Registr vykázané péče. (Národní registr hrazené zdravotní péče)

- T04 Řešení autentizace a autorizace zdr. pracovníků a pacientů v resortu zdravotnictví, zřizování prístupů, řízení souhlasů a přístupu k informacím, identifikace pacienta

- T05 ePreskripce

- T06 Sdílení a výměna dat mezi poskytovateli zdravotních služeb - eŽádanka, sdílení zdravotní péče

- T07 Portál na podporu informovanosti ve zdravotnictví (pro občana, lékaře, zdravotnického manažera); přístup k zdravotnímu záznamu

- T12 Národní kontaktní místo elektronického zdravotnictví

- T13 Interoperabilita aplikací a služby eGovernment

- T14 Mezinárodní interoperabilita

- T15 Otevřená data

- Centrální sdílené služby - IDRR

- Přiloha č. 3 - Návrh komponent architektury pro poskytování sdílených služeb

Tyto výstupy mají společnou strukturu, jejíž první kapitolou je zformulování východisek. Zpracovávaná architektonická vize je založena na reálných potřebách jednotlivých aktérů zmapovaných v katalogu potřeb. Další kapitolou je uplatněná metodika a použité architektonické principy. Následuje popis současného stavu. Tam, kde je potřeba, je tento strav popsán v notaci Archimate pro popis Enterprise architektur. Hlavním výstupem je popis cílového stavu, který je žádoucí dosáhnout dle cílů NSeZ a stanovených principů rozvoje $v$ rezortu zdravotnictví, tak i Národním architektonickým plánem ČR stanovaným odborem eGovernmentu při MV ČR. Na závěr je uvedena jednoduchá GAP analýza.

\section{Hlavní aktuálně řešená témata dle priorit Akčního plánu}

\subsection{Klíčová aktivita číslo 3}

Vybudování Integrovaného Datového Rozhraní Rezortu pro komunikaci informačních systémů a sdílení dat (IDRR) pokrývá řešení architektonických témat Národních referenčních registrů (T01), dále klíčové téma řešení identity (T04) a napojení 
na Základní registry pro zprostředkování referenční datové základy ČR pro poskytovatele zdravotních služeb $(T 13, T 14)$ a řeší i části tématu sdílení a výměnu dat mezi poskytovateli v oblasti správy souhlasů a mandátů a jejich vazby na registr pojištěnců (T06). Budovaný informační systém IDRR zprostředkuje přístup k otevřeným datům rezortu pro jejich další využití.

Aktivita číslo 3 bude realizována projektovým záměrem vytvoření Integrovaného datového rozhraní resortu (IDRR), který vytvárí resortní sběrnici (tzv. resortní service bus) a související infrastrukturu. Obdobné resortní sběrnice vytvářejí i jiné resorty, postupují přitom v souladu s doporučeními Hlavního architekta státní a veřejné správy zř́zeného v gesci MV ČR a realizují tak sdílený datový fond ČR.

Projekt IDRR poskytuje podporu pro zajištění interoperability informačních systémů a služeb v resortu zdravotnictví, napojení na služby eGovernmentu, zejména napojení na služby Základních registrů, eGON Service Bus a Národní identitní autoritu. Propojuje se na Národní kontaktní místo elektronického zdravotnictví, které zajišťuje interoperabilitu v rámci EU (např. v intencích projektu epSOS).

Projekt IDRR je v souladu s NSeZ koncipován tak, aby:

- poskytoval základní technickou infrastrukturu nezbytnou pro rozvoj služeb elektronického zdravotnictví;

- poskytoval autoritativní data pro elektronizované procesy ve zdravotnictví, včetně procesư řešíci životní situace pacientů a zdravotnických profesionálů;

- poskytl autoritativní registry: Národní registr zdravotnických pracovníků a Národní registr poskytovatelů zdravotních služeb; registry budou autoritativním zdrojem údajů pro identifikaci subjektů a zprostředkují zákonem stanovené informace pro oprávněné osoby, registry slouží mimo jiné i pro nastavování jejich práv a odpovědností ve světě elektronické komunikace;

- poskytoval službu pro ztotožňování pacientů, která je vyžadována poskytovateli zdravotních služeb;

- poskytoval zprostředkování služby autentizace klienta zdravotních služeb prostřednictvím národní identitní autoritu NIA;

- poskytoval služby identifikace zdravotnického pracovníka, identifikace zdravotnického zařízení (poskytovatel zdravotní péče), tato služba zajistí a posílí právní a organizační jistoty a kontinuitu při práci s elektronickými písemnostmi a zdravotnickou dokumentací;

- zprostředkovával služby pro využití datového fondu České Republiky (referenčních dat, datových fondů orgánů veřejné moci OVM) a zajištoval komunikaci na sdílené služby eGovernmentu pro subjekty nemající oprávnění prístupu do Základních registrů (což je v resortu zdravotnictví běžné, poskytovatelé nejsou z principu orgány veřejné moci OVM);

- zajištoval autentizaci, autorizaci a řízení oprávnění zdravotnických pracovníků;

- zajištoval řízení souhlasů a mandátu ve zdravotnictví;

- zajištoval podpůrné služby pro zaručenou výměnu dat;

- zajištoval funkcionalitu indexu zdravotnické dokumentace;

- poskytoval veřejná data i neveřejná data (číselníky, DASTA, GISové informace);

- poskytoval otevřená data (OPEN DATA).

\subsection{Klíčová aktivita číslo 2}

ePreskripce, př́prava postupného náběhu plnohodnotné elektronické preskripce.
První etapa byla spuštěna zavedením plošné elektronické preskripce pro všechny oprávněné zdravotnické pracovníky a dala by se nazvat eRecept, protože kromě elektronického předpisování neposkytuje mnoho dalších funkcionalit. Faktem je, že její plošné zavedení rozhýbalo celý resort zdravotnictví a nastartovalo procesy elektronizace.

První etapa má několik úskalí, které názorně demonstrují, jak dopadá realizace projektu bez potřebné infrastruktury.

První úskalí je neexistence Národního registru zdravotnických pracovníků. Důsledkem je povinnost pro správce a provozovatele řešení ePreskripce (SÚKL) vytvořit náhradní způsob řešení. Vznikl tedy "registr" (evidence) přihlašovaných lékařủ do systému ePreskripce.

Dopady:

- Lékař si musí vytvořit v pořadí další přístupové údaje do Centrálního úložiště (další certifikát) a absolvovat zdlouhavý proces registrace.

- Nově tvořená evidence je duplicitní k registru zdravotnických pracovníků a není aktualizována při změnách na straně lékaře (změna jména, způsobilost, geografické údaje, príslušnost ke zdravotnickému zařízení, apod.)

- SÚKL si musel vytvořit př́stup do Základních registrů, aby mohl ztotožňovat pacienty.

- SÚKL nemá př́stup do registru pojištěnců, aby mohl zjistit př́slušnost pacienta ke zdravotní pojištovně.

- SÚKL nemá informaci o tom kdo je registrující lékař pacienta.

Další úskalí spočívají v systému nahlížení do lékového záznamu. Vlastně jej má pouze předepisující lékař a to pouze na recepty, které sám vypsal. Pacient může $v$ této etapě již do svého záznamu nahlédnout, podmínkou je získání identity od Národní identitní autority.

SÚKL pacienty neeviduje (přebírá jejich identitu z NIA), nemá jejich databázi a proto ani nemůže vést správu souhlasů a mandátů.

Není řešen př́stup zákonných zástupců za nezletilé a nesvéprávné, především kde a jakým způsobem bude dokládáno jejich právo zastupovat tuto osobu. Obdobně není řešena otázka prístupu príbuzných u starých, nemohoucích pacientů.

Druhá etapa navazuje zpř́stupněním lékového záznamu a je pragmatickým projektem, který řeší prínosy dosažitelné v krátkém časovém období roku 2018.

Důležitým aspektem, který se bude promítat do budoucího řešení centrálně budovaných služeb je řešení přístupů $k$ tomu lékovému záznamu. Ke zvládnutí tohoto úkolu v celé jeho šíri a s respektem na Nařízení Evropského parlamentu a Rady (EU) 2016/679 (GDPR) ze dne 27. dubna 2016 o ochraně fyzických osob (v souvislosti se zpracováním osobních údajů a o volném pohybu těchto údajů) je nutné znát identitu lékaře a pacienta, prípadně i osobu pověřenou mandátem. Dále je potřeba zajistit právo pacienta na udělení souhlasu s nahlížením do jeho lékového záznamu.

Tyto aspekty jsou uvedeny proto, že mají dopad na architekturu celého řešení. Pro pochopení problematiky uvádíme informace potřebné k nastavení celého systému řízení prístupů.

\section{Pacient}

V obecné rovině prístup do lékového záznamu bude mít pacient (občan ČR a fyzická osoba se státem garantovanou identitou $v$ NIA, tj. i cizinec registrovaný v základních registrech, byt $s$ přechodným pobytem $v$ ČR).

- Pacient má právo sám rozhodnout o tom, zda si přeje, aby byl veden jeho pacientský lékový záznam. Souhlas pacien- 
ta musí být poučený a pacient musí mít právo svůj souhlas dodatečně odvolat.

- Pacient má právo rozhodnout o tom, že vedení jeho lékového záznamu má být ukončeno.

- Př́stupy podmíněné existencí služby správa souhlasů a mandátů:

- Pacient má možnost nad rámec obecných pravidel rozširíit přistup ke svému lékovému záznamu zvolenému lékaři, lékárníkovi či jiné osobě (např. rodinnému př́slušníkovi). Přístup může být trvalý, jednorázový či časově omezený. Př́istup může být pacientem opět odvolán.

- Pacient (nebo jeho zákonný zástupce) může sám určit, kterému lékaři, kterému zdravotnickému zařízení, případně které kategorii zdravotnických pracovníků je jeho lékový záznam přístupný, přičemž praktický lékař, u kterého je pacient registrován, by neměl být z přistupu $\mathrm{k}$ vedenému lékovému záznamu nikdy vyloučen.

- Nemohoucí, nesvéprávní a děti v dětských domovech - musí být řešeno formou mandátů.

Výše uvedená práva Ize k 1.1.2019 naplnit částečně. Aktuální technické prostředky zvládají pouze systém, kdy v případě, že pacient ponechá nastavený systém vedení lékového záznamu OPT OUT, bude jeho lékový záznam (výpis z CURP) dostupný všem lékařům.

\section{Realizovatelné rešení:}

Zavedení přechodného období, ve kterém bude nastaven počáteční systém OPT OUT, a v tomto období bude možné ze strany pacienta vyjádřit souhlas/nesouhlas s vedením lékového záznamu. Po skončení tohoto období by došlo k automatickému souhlasu u všech pacientů, kteří by nevyjádřili nesouhlas. Přechodné období po dobu 6 měsíců.

Zaváděná povinnost pro lékaře:

Při každém náhledu bude lékař povinně vyplňovat roli, ve které přistupuje:

- registrující lékař,

- ošetřující lékař,

- ostatní - jako např. záchranná služba.

Prístupy budou logovány a pacient si může spustit službu realizovanou SÚKLem - „Výpis přistupujících do mého lékového záznamu" a případně vznést stížnost na neoprávněný přístup (kterou se pak někdo musí zabývat, nebot' občan uplatňuje právo na ochranu citlivých údajů vedených státem).

\section{Lékař}

Současný systém není schopen selektovat lékaře po odbornostech (DB lékařu takovou informaci neobsahuje), $v$ horizontu realizace k 1. 1. 20119 je potřeba zvolit náhradní způsob přidělování prístupů.

Přístupy evidované a logované, kdy lékař vyznačí roli, ve které vstupuje do lékového záznamu pacienta, viz povinnosti lékaře výše.

- Aktuálně registrující praktický lékař bude mít přistup do lékového záznamu svého pacienta

- Lékař provádějící neodkladnou péči má potřebu a právo nahlížet do lékového záznamu bez omezení

- Samostatnou skupinou jsou lékaři záchranné zdravotní služby a emergency, kteří by měli mít automatický přístup do lékového záznamu pacienta
- Přístupy podmíněné existencí služby správa souhlasů a mandátů:

- př́stup mají ošetřující lékaři a farmaceuti po pacientově souhlasu uděleném jednorázově či trvale, který může být kdykoliv odvolán,

- přístup do lékového záznamu by obecně měl mít lékař, který vyšetřuje pacienta a následně předepisuje léčivý prípravek,

- kterýkoliv lékař s přístupem do pacientského lékového záznamu má právo se dozvědět, že pacientský lékový záznam není na přání pacienta veden a také má právo spolehnout se na to, že pokud lékový záznam veden je, jsou v něm uvedena všechna pacientova data.

\section{Realizovatelné řešení:}

Zavedení přechodného období, ve kterém bude nastaven počáteční systém OPT OUT, a v tomto období bude možné ze strany pacienta vyjádřit souhlas/nesouhlas s vedením lékového záznamu. Po skončení tohoto období by došlo k automatickému souhlasu u všech pacientů, kteří by nevyjádřili nesouhlas. Přechodné období po dobu 6 měsíců.

\section{Lékárník}

Přístup lékárníka do lékového záznamu může být řešen tak, že při výdeji léků bude lékárníkovi otevřen výpis na dobu výdeje.

Oficiální přístup ke komplexní informaci o užívaných léčivých přípravcích pacientem je pro lékárníka nová skutečnost, která umožní provádět skutečně dispensační činnost při výdeji léku. Vytvárí ale nové vztahové otázky ve věci odpovědnosti mezi lékařem a lékárníkem. I zde platí, že systém není schopen řešit individuální prístup určité lékárny resp. lékárníka, v horizontu realizace k 1.1. 2019.

\section{Závěr a doporučení}

Z výše uvedených skutečností vyplývá význam služeb poskytování autoritativních dat z národních registrů a služeb identifikace pacienta a lékaře a dále význam registru pojištěnců navázaný na správu souhlasů a mandátů. Tyto poznatky se musí promítnout do architektury řešení centrálně poskytovaných služeb systémem IDRR.

\subsection{Klíčová aktivita číslo 4}

\section{Výměna zdravotnické dokumentace.}

Podpora výměny zdravotnické dokumentace je rozsáhlým souborem aktivit, které je nutné realizovat postupně. Dotýká se všech poskytovatelů zdravotních služeb a vyžaduje citlivé provádění změn, aby se podařilo smysluplně a úspěšně překonat počáteční bariéry a zavedené postupy, $v$ souladu se záměry formulovanými Národní strategií elektronického zdravotnictví.

Smyslem aktivity je vybudování nezbytné infrastruktury pro výměnu zdravotnické dokumentace a dále specifikování legislativních, technických, bezpečnostních a obsahových standardů pro realizaci sdíleného zdravotního záznamu (EHR, PHR). Stát bude výchozím garantem systému sdílení zdravotnických dat a to i v situacích kdy data nebudou přenášena přes centrální uzel.

Cílem elektronické výměny je bezpečné, adresné, a garantované zajištění přenosu zdravotnické dokumentace včetně vystavení elektronické žádanky pro zajištění vyžádané péče mezi poskytovateli.

Architektura řešení musí zahrnovat napojení na systémy správy př́stupů, který vymezuje okruh osob oprávněných přistupovat k dokumentaci. Musí řešit způsob prokazování jejich 
totožnosti a oprávnění (autentizace a autorizace). Musí být odlišen přístup za normálních okolností (plánované vyšetření u specialisty) a ve zvláštních prípadech (urgentní stavy) a to podle platné legislativy.

$V$ architektuře jsou zohledněny dva způsoby výměny:

1. Výměna zdravotnické dokumentace mezi poskytovateli naprímo (PACS, eZpráva, Rediment,...), kde je potřeba dořešit nastavení pravidel, které tyto systémy musí splňovat:

- Zajištění bezpečnosti a ochrany osobních údajů

- Identifikaci pacienta a lékaře, příslušnost lékaře ke zdravotnickému zařízení

- Identifikaci pacienta (ztotožňování v základních registrech, prípadně ověření identity $v$ registru pojištěnců)

- Zabezpečení procesů a systémů u poskytovatele zdravotních služeb tak, aby byla dokumentace doručena pouze adresovanému př́jemci zabezpečeným způsobem

- Zajištění souhlasu pacienta

2. Výměna zdravotnické dokumentace prostřednictvím centrálních systémů

- Zajištění služeb Indexu zdravotnické dokumentace informační systém spravovaný MZ ČR shromaždující přehled o existující dostupné zdravotnické dokumentaci, uložené u poskytovatelů zdravotních služeb. Index sbírá a uchovává informace od poskytovatelů zdravotních služeb, která pacient navštívil a kde vznikla zdravotnická dokumentace, včetně obrazové a jiné multimediální dokumentace.

- Musí být zajištěna správa př́stupů do Indexu

- Musí být zajištěno vedení záznamů o nahlížení do zdravotnické dokumentace - o každém vyžádání a poskytnutí dokumentace bude veden záznam se zdůvodněním účelu nahlédnutí. Tento záznam bude dostupný pacientovi a kontrolním orgánům.

- Bude zajištěno propojení na Národní kontaktní místo (dále NCP) pro přeshraniční výměnu ZD.

\section{Infrastruktura potřebná k realizaci této kličové aktivity}

Výměna zdravotnické dokumentace předpokládá realizaci řady služeb, zejména existencí identifikovaných a ztotožněných pacientů a lékařů, $z$ čehož plyne potřeba autoritativních registrů NRZP, NRPZS a registru pojištěnců provázaných na Základní registry.

Centrální služby elektronického zdravotnictví potřebné pro výměnu zdravotnické dokumentace:

1. Zaručená výměna dat - brána výměny a sdílení, která zabezpečuje komunikační uzel pro výměnu a sdílení zdravotní dokumentace (dále ZD) v asynchronním režimu. Služba by měla být poskytována systémem IDRR a zabezpečuje výměnu v př́ipadě, že žadatel, nebo příjemce nemá $k$ dispozici online službu/rozhraní pro vystavení již zpracované dokumentace. Nepředpokládá se náhrada funkčních systémů PACS sdílející obrazovou dokumentaci.

2. Index zdravotní dokumentace - obsahuje informace o existenci záznamů zdravotní dokumentace pacientů u jednotlivých poskytovatelů zdravotních služeb. Systém zabezpečuje služby:

\section{- Zápis do indexu}

- Prohližení indexu

3. Systém správy souhlasů k ZD - spravuje souhlasy se sdílením zdravotní dokumentace pacienta. Poskytuje služby:
- Evidence udělených souhlasů

- Správa implicitních souhlasů

- Ověření souhlasu

4. Systém správy mandátů

- Evidence udělených mandátů

- Správa implicitních mandátů

- Ověření mandátů

5. Systém Vykázaná peče, který zabezpečuje služby

- Vystavení žádanky

- Převzetí žádanky

- Vystavení nálezu

- Převzetí nálezu

6. Poskytování informací prostřednictvím Národního zdravotnického informačního portálu

- Služby vystavování dat z datových zdrojů prostřednictvím systému IDRR

- .....

7. Služby autentizace

- Autentizace klienta zdravotních služeb

- Autentizace zdravotnického pracovníka

- Autentizace pověřené osoby

- Autentizace systému přistupujícího k zdravotnické dokumentaci

8. Služby autorizace

- Kontrola oprávnění zdravotnického subjektu na služby včetně kontroly mandátů

9. Notifikační služby pro klienta zdravotních služeb

- Odeslání notifikace

- Správa notifikací

Správa souhlasů a mandátů pro přístup ke zdravotnické dokumentaci poskytne občanovi možnost elektronického (ale i písemného) zadávání nových souhlasů, změnu a zrušení zadaných souhlasů pro lékaře, poskytovatele zdravotních služeb a dalším osobám (např. rodinný příslušník - otec, matka,...). Centrální služba umožní občanovi:

- možnost volby, zda bude jeho elektronická zdravotnická dokumentace (resp. elektronický zdravotní záznam) jako celek, či jen její části (např. index zdravotnické dokumentace, elektronický zdravotní záznam, lékový záznam), sdílena či nikoliv,

- možnost rozhodnout o nastavení přístupu lékařů, lékárníků, zdravotnických zařízení, prípadně, pro které kategorie zdravotnických pracovníků budou jeho elektronické zdravotní záznamy př́stupné, a to v různých životních situacích (ošetřující lékař, záchrana života, vydávající lékárník, konzultant atp.),

- možnost nad rámec výše uvedených pravidel přístup ke svému záznamu a osobnímu účtu kdykoliv modifikovat,

- přístup může být trvalý, jednorázový či časově omezený, prístup může být pacientem opět odvolán,

- pro zajištění ochrany osobních údajů a posílení ochrany soukromí má pacient (či jeho zákonný zástupce) príistup k auditním informacím o prístupu všech subjektů k jeho elektronické zdravotnické dokumentaci či sdílené části elektronického zdravotního záznamu (EHR/PHR). 


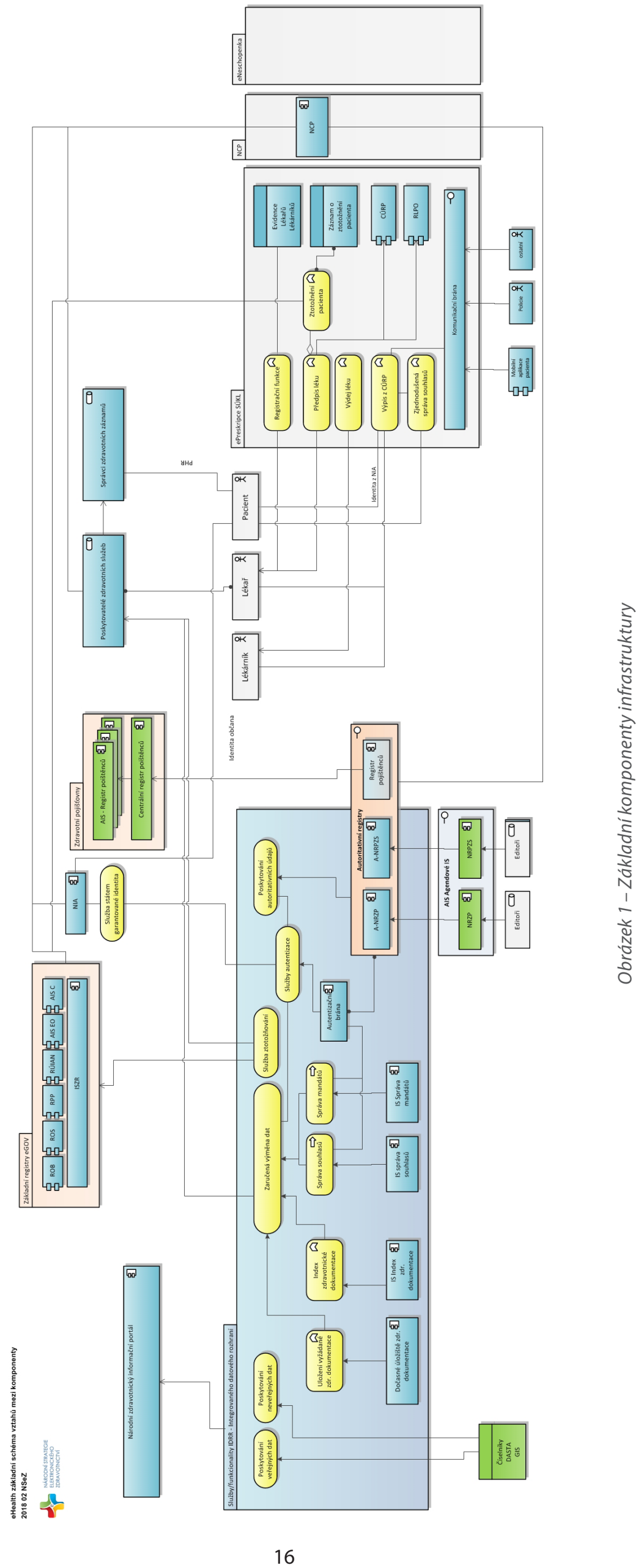




\subsection{Klíčová aktivita číslo 7}

\section{Portál elektronického zdravotnictví}

Cílem této aktivity je zejména vytvoření vstupního bodu pro aktivní př́stup občanů k ověřeným a zaručeným informačním zdrojům o zdravém způsobu života, o postupech a metodách zdravotní péče, o síti zdravotnických zařízení a jejich kvalitativních parametrech, o možnostech ochrany a podpory zdraví, o prevenci a preventivních programech, o nemocech, o programech péče o chronicky nemocné, nástroje $\mathrm{k}$ aktivní roli občana. Zajištění přiměřené orientace občanů, zdravotnických profesionálů a pracovníků správních orgánů, vedoucí k rozvoji využití informací ve vhodných informačních zdrojích. Podpora při řešení životních situací v oblasti nejen zdravotní péče, ale i správních agend.

Zdrojem dat pro publikování bude zejména systém IDRR $s$ jeho službami. Dalšími zdroji informací bude vybudovaný systém editorů, kteří budou publikovat informace $v$ definovaném procesu jejich schvalování. Informační systém Portál bude úzce navázán na portál občana budovaný MV ČR a to jak grafickou úpravou, tak i filozofií ovládání. Cílem je usnadnit občanům orientaci při řešení jeho životních situací bez ohledu na to v jakém informačním systému se nachází.

\section{Zjednodušená architektura infrastrukturních služeb a jejich provázanost.}

Na obrázku č. 1 je znázorněna architektura základních komponentů, služeb a funkcí které poskytují. Jsou znázorněny nejzákladnější vazby mezi jednotlivými komponenty.

Architektura prezentuje centrálně vytvářené služby elektronického zdravotnictví potřebné pro zajištění výše uvedených klíčových aktivit a cílů NSeZ.

\section{Závěr}

Článek bude zdrojem pro specifikaci budovaných funkcionalit centrálně budované infrastruktury a pro koncipování zákona o elektronickém zdravotnictví. Názorně totiž dokumentuje provázanost jednotlivých komponentů a dává do souvislostí funkční bloky, které byly v minulosti budovány izolovaně a vytvářely tak duplicitní systémy a funkcionality.

\section{Literatura}

[1.] SCHVÁLENÁ NÁRODNÍ STRATEGIE ELEKTRONICKÉHO ZDRAVOTNICTVÍ NA OBDOBÍ 2016 - 2020, Strategie ve znění schváleném Usnesením vlády ČR ze dne 28.11.2016 č. 1054

[2.] MINISTERSTVO ZDRAVOTNICTVÍ ČESKÉ REPUBLIKY. Posouzení realizovatelnosti vybraných oblastí Národni strategie elektronického zdravotnictví. Verze 2.04. Praha, 2016.

[3.] MINISTERSTVO ZDRAVOTNICTVÍ ČESKÉ REPUBLIKY. AkČní plán k Národní strategii elektronického zdravotnictví ČR 2016 - 2020. Verze 1.00. Praha, 2017.

[4.] MINISTERSTVO ZDRAVOTNICTVÍ ČESKÉ REPUBLIKY. Cílová architektura tématu T01 - Národní registr poskytovatelů zdravotních služeb a Národní registr zdravotnických pracovníků. Verze 1.00. Praha, 2016.

[5.] MINISTERSTVO ZDRAVOTNICTVÍ ČESKÉ REPUBLIKY. Cílová architektura tématu T04 - Řešení autentizace a autorizace zdravotnických pracovníků a pacientů v resortu zdravotnictví, zřizování prístupů, řízení souhlasů a prístupu k informacím, identifikace pacienta. Verze 1.00. Praha, 2016

[6.] MINISTERSTVO ZDRAVOTNICTVÍ ČESKÉ REPUBLIKY. Cílová architektura tématu T06 - Sdílení a výměna dat mezi poskytovateli zdravotních služeb-ežádanka, sdílení zdravotni péče. Verze 1.00. Praha, 2016.
[7.] MINISTERSTVO ZDRAVOTNICTVÍ ČESKÉ REPUBLIKY. Př́loha 1.

[8.] Vytvoření architektury budoucího stavu registrů ve zdravotnictví. Verze 1.00. Praha, 2016.

[9.] MINISTERSTVO ZDRAVOTNICTVÍ ČESKÉ REPUBLIKY. Př́loha 2. Analýza a návrh řešení dopadů nařizení Evropského parlamentu a Rady (EU) č. 910/2014 o elektronické identifikaci a službách vytvářejících důvěru pro elektronické transakce. Verze 1.00. Praha, 2016.

[10.] MINISTERSTVO ZDRAVOTNICTVÍ ČESKÉ REPUBLIKY. Př́loha 3.

[11.] Návrh komponent architektury pro poskytování sdílených služeb. Verze 1.00. Praha, 2016.

Použitá literatura je zveřejněna na stránkách Národní strategie elektronického zdravotnictví, www.nsez.cz

\section{Kontakt}

\section{Ing. Jiří Borej, CGEIT}

Ministerstvo zdravotnictví

Palackého náměstí 4

12801 Praha 2

tel: 224972635

e-mail: jiri.borej@mzcr.cz 